REVIEW

\title{
The role of estrogens for male bone health
}

Claes Ohlsson and Liesbeth Vandenput

Center for Bone Research, Division of Endocrinology, Department of Internal Medicine, Institute of Medicine, Sahlgrenska Academy, University of Gothenburg, SE-41345 Gothenburg, Sweden

(Correspondence should be addressed to C Ohlsson; Email: claes.ohlsson@medic.gu.se)

\begin{abstract}
Sex steroids are important for the growth and maintenance of both the female and the male skeleton. However, the relative contribution of androgens versus estrogens in the regulation of the male skeleton is unclear. Experiments using mice with inactivated sex steroid receptors demonstrated that both activation of the estrogen receptor (ER) $\alpha$ and activation of the androgen receptor result in a stimulatory effect on both the cortical and trabecular bone mass in males. ER $\beta$ is of no importance for the skeleton in male mice while it modulates the ER $\alpha$-action on bone in female mice. Previous in vitro studies suggest that the membrane $G$ protein-coupled receptor GPR30 also might be a functional ER. Our in vivo analyses of GPR30-inactivated mice revealed no function of GPR30 for estrogen-mediated effects on bone mass but it is required for normal regulation of the growth plate and estrogen-mediated insulin-secretion. Recent clinical evidence suggests that a threshold exists for estrogen effects on bone in men: rates of bone loss and fracture risk seem to be the highest in men with estradiol levels below this threshold. Taken together, even though these findings do not exclude an important role for testosterone in male skeletal homeostasis, it is now well-established that estrogens are important regulators of bone health in men.
\end{abstract}

European Journal of Endocrinology 160 883-889

\section{Introduction}

Peak bone mass is higher in men than in women. After peak bone mass is reached, both men and women lose bone but the bone loss is accelerated after menopause in women. Compared with women, men have greater bone strength, resulting in fewer fractures. This is mainly due to a larger cortical bone size in men compared with women, resulting from more bone deposition at the periosteal bone surface in men during sexual maturation. Sex steroids are important for the skeletal growth and maintenance of both the female and the male skeleton (1). The effects of testosterone (T) can be exerted either directly through the androgen receptor $(A R)$ or indirectly via aromatization to estradiol $\left(\mathrm{E}_{2}\right)$ and activation of estrogen receptor (ER) $\alpha$ and/or $\beta$ (listed as ESR1 and ESR2 in the HUGO Database). All three of these sex steroid receptors are expressed in bone (2-4). In addition, it has recently been suggested from in vitro experiments that the membrane G protein-coupled receptor GPR30 (listed as GPER in the HUGO Database) is also a functional ER (Fig. 1) (5). In this review, some of our experimental animal and clinical studies exploring the role of estrogens for the skeleton in males will be discussed.

\section{Estrogen receptors and the male skeleton: lessons from mouse studies Cortical bone}

The larger cortical bone size in males compared with females is, at least partly, due to differences in sex steroid exposure during sexual maturation. Experiments by Venken et al. using male $\mathrm{AR}^{-/-}$mice have clearly demonstrated that $\mathrm{AR}$ activation results in cortical radial bone expansion (6). In addition, we found that male $\mathrm{ER} \alpha^{-/-}$but not $\mathrm{ER} \beta^{-/-}$mice displayed reduced cortical radial bone growth during sexual maturation, demonstrating that $\mathrm{ER} \alpha$ but not $\operatorname{ER} \beta$ activation is also required for a normal cortical radial bone expansion in males during growth (Fig. 2) (7). As the cortical radial bone growth was affected during sexual maturation in the male $\mathrm{ER} \alpha^{-/-}$mice, one might speculate that the $\mathrm{GH} /$ insulin-like growth factor I (IGF-I) axis is involved in this effect. In this context, we and others have shown that a major part of serum IGF-I is liver-derived and that male $\mathrm{ER} \alpha^{-7-}$ mice had a similar cortical bone phenotype as mice with liver-specific IGF-I inactivation (7-11). Importantly, serum IGF-I levels were reduced in the $\mathrm{ER} \alpha^{--}$mice, suggesting that these decreased serum IGF-I levels might mediate the reduced cortical radial bone growth seen in male $\mathrm{ER} \alpha^{-/-}$mice during 


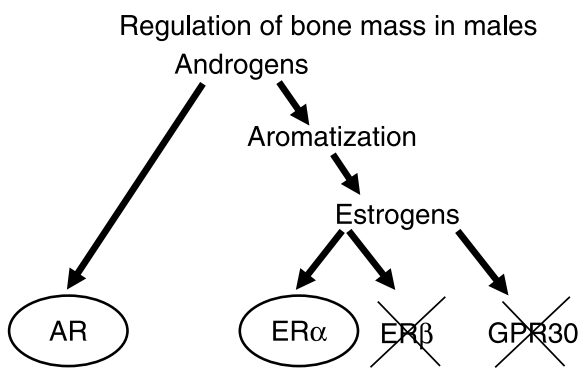

Figure 1 Summary of possible pathways for androgens to regulate bone mass in males. Experimental animal studies using mouse models with inactivation of the androgen receptor (AR), estrogen receptor $\alpha(E R \alpha), E R \beta$ or the recently suggested ER GPR30 have demonstrated that the AR and $\mathrm{ER} \alpha$, but not $\mathrm{ER} \beta$ or GPR30, are involved in the regulation of cortical and trabecular bone in males.

sexual maturation (Fig. 2). We therefore, proposed that a normal pubertal cortical bone expansion in males might be dependent on an early ER $\alpha$-mediated stimulation of the GH/IGF-I axis.

\section{Trabecular bone}

Similar to that seen in cortical bone, both AR and ER $\alpha$ but not ER $\beta$ activation regulate trabecular bone mass in male mice (Fig. 1) (12-14). To directly compare the effect of ER activation on trabecular bone in vivo with the effect of AR activation, orchidectomized wild type (WT) and ER-inactivated mice were treated with the non-aromatizable androgen dihydrotestosterone (DHT), $\mathrm{E}_{2}$ or vehicle. Both $\mathrm{ER} \alpha$ and AR but not ER $\beta$ activation preserved the amount of trabecular bone. ER $\alpha$ activation resulted both in preserving the thickness

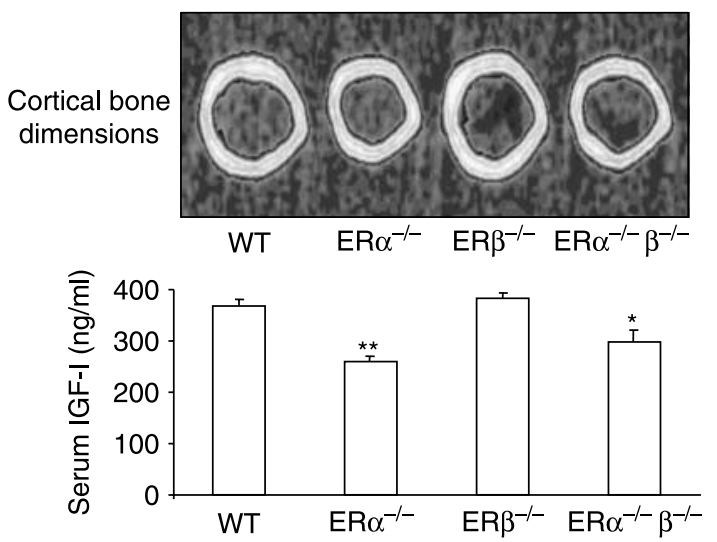

Figure 2 Reduced cortical radial bone growth and serum IGF-I levels in male $\mathrm{ER} \alpha^{-1-}$ and $\mathrm{ER} \alpha^{-1-} \beta^{-1-}$ double knock out but not $\mathrm{ER} \beta^{-1-}$ mice during sexual maturation. The upper panel displays representative mid-diaphyseal peripheral quantitative computer tomography sections of the femur, and in the lower panel, serum IGF-I levels of mice from the different genotypes are shown.

${ }^{\star} P<0.05,{ }^{* \star} P<0.01$ versus wild type (WT). (Adapted from Vidal et al. (7) with permission from the National Academy of Sciences, USA). and number of trabeculae. By contrast, AR activation exclusively preserved the number of trabeculae (13). Furthermore, the effects of $E_{2}$ could not be mediated by the AR, and the effects of DHT were not reduced in ER-inactivated mice (Fig. 3). Thus, the in vivo bone-sparing effect of $\mathrm{ER} \alpha$ activation is distinct from the bone-sparing effect of AR activation in adult male mice. Because these two pathways are clearly distinct from each other, we proposed that a combined treatment of selective ER and AR modulators might be beneficial in the treatment of male osteoporosis (13). In contrast to the IGF-I - mediated effects of $\mathrm{E}_{2}$ on cortical bone during sexual maturation, the effects of $\mathrm{E}_{2}$ on trabecular maintenance were not associated with the GH/IGF-I axis and seem to result from direct action of $\mathrm{E}_{2}$ on bone.

\section{Estrogen receptor $\boldsymbol{\beta}$ modulates $\mathrm{ER} \alpha$ activity in female but not male mice}

Similar to that seen in males, ER $\alpha$ is the principal ER for the regulation of both trabecular and cortical bone in female mice (15-18). However, female ER $\beta$ inactivated mice have an increased cortical bone area, resulting in a loss of feminization of the cortical bone size (Fig. 4A) (19). Furthermore, female $E R \beta^{-/-}$mice are partly protected against age-related trabecular bone loss (Fig. 4B) (20), suggesting that an ER $\beta$ antagonist might be useful in the treatment of post-menopausal osteoporosis. Thus, although ER $\alpha$ is the principal ER for the female skeleton, its activity can be modulated by $E R \beta$. Interestingly, when we evaluated the effect of $E_{2}$ in female bone using global gene expression analyses, we found that the magnitude of the stimulatory effect of $E_{2}$ on estrogen-regulated transcripts was in general more pronounced in the ER $\beta^{-1-}$ mice than in the WT mice (21). These data were the first to demonstrate in vivo that $\operatorname{ER} \beta$ has the capacity to reduce $\operatorname{ER} \alpha$ regulated gene transcription in a global manner. This inhibitory role of $E R \beta$ on $E R \alpha$ activity is now generally believed to be a major function of ER $\beta$ in several tissues, including for the regulation of tumorigenesis. These data support a 'yin yang' relationship between ER $\alpha$ and ER $\beta$ in the female bone and possibly in other tissues. It remains, however, to be determined why ER $\beta$ modulates the effect of $\mathrm{ER} \alpha$ on the skeleton in female but not male mice.

\section{Evaluation of GPR30 as a potential ER in bone}

In vitro studies suggest that, besides the two known nuclear ERs $\alpha$ and $\beta$, the membrane GPR30 is also a functional ER $(5,22)$. GPR30 was shown to bind $E_{2}$ with high affinity in vitro $(5,22)$ and to mediate estrogen-promoted proliferative signaling in an estrogen-sensitive but ER-negative breast cancer cell line 


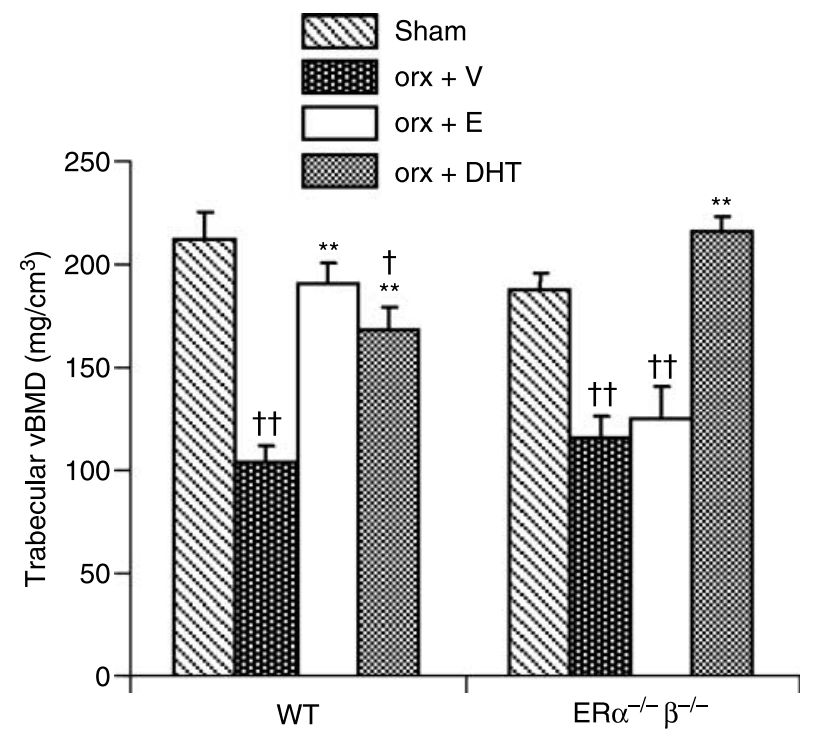

Figure 3 The in vivo trabecular bone-sparing effect of ER activation is distinct from the trabecular bone-sparing effect of AR activation in males. To directly compare the effect of ER activation on trabecular bone in vivo with the effect of AR activation, 9-month-old orchidectomized (orx) wild type (WT) and ER-inactivated mice $\left(\mathrm{ER} \alpha^{-1-} \beta^{-l-}\right)$ were treated with the non-aromatizable androgen dihydrotestosterone (DHT), $\mathrm{E}_{2}$ or vehicle (V). Trabecular volumetric BMD of the femur is shown, demonstrating that the effects of $E_{2}$ could not be mediated by the AR, and the effects of DHT were not reduced in ER-inactivated mice. Values are given as means \pm S.E.M. ${ }^{\star \star} P<0.01$ versus orx $+\mathrm{V}$; ††, $P<0.01 ; \dagger, P<0.05$ versus sham. (Reproduced from Movérare et al. (13) with permission from the National Academy of Sciences, USA).

$(23,24)$ and human endometrial cells (25). Furthermore, it was shown in vitro to mediate estrogendependent kinase activation as well as transcriptional responses $(26,27)$. However, it remains to be determined if GPR30 is an ER in vivo for bone metabolism or other phenotypes. We therefore, recently investigated the possible role of GPR30 as a functional ER for the regulation of skeletal parameters using GPR30 inactivated mice (28). The estrogenic responses on most of the investigated parameters, including increase in bone mass (total body bone mineral density (BMD), spine BMD, trabecular BMD, cortical thickness), increase in uterine weight, fat mass reduction, and increase in bone marrow cellularity, were similar for all the investigated $\mathrm{E}_{2}$ doses in WT and GPR 30 inactivated mice, demonstrating that GPR30 is not required for normal estrogenic responses on several major wellknown estrogen-regulated parameters. On the other hand, high dose $E_{2}$ treatment reduced longitudinal bone growth, reflected by decreased femur length and distal femur growth plate height, in the WT mice but not in the GPR30 inactivated mice, supporting a role of GPR30 for a normal estrogenic response in the growth plate. In addition, we found that GPR30 mediates $\mathrm{E}_{2}$-stimulated insulin release in vivo (29).
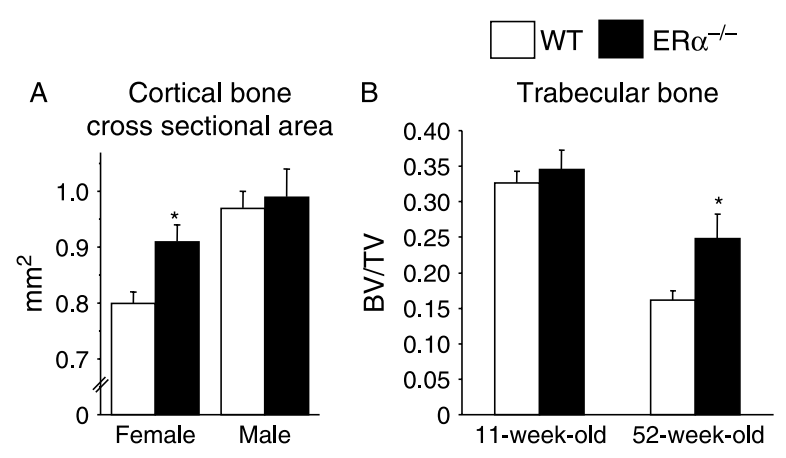

Figure $4 \mathrm{~A}$ role of ER $\beta$ for the skeleton in female mice. $(A)$ Female $E R \beta^{-1-}$ mice have an increased cortical bone area, resulting in a loss of feminization of the cortical bone size. Cortical cross-sectional bone area in the mid-diaphyseal region of the femur in 11-week-old mice. ${ }^{\star} P<0.01$ versus wild type (WT). (Adapted from Windahl et al. (19)). (B) Female $E R \beta^{-1-}$ mice are partly protected against age-dependent trabecular bone loss. Histomorphometric analyses of bone volume/total volume (BV/TV) for the distal metaphyseal region in the femur of 11 - and 52 -week-old female mice. ${ }^{*} P<0.05$ versus WT. Values are means \pm S.E.M. (Adapted from Windahl et al. (20) with permission from the American Society for Bone and Mineral Research).

Thus, although GPR30 does not seem to be a functional ER in several major ER-responsive tissues, it mediates $\mathrm{E}_{2}$-stimulated insulin release and is required for a normal estrogenic response in the growth plate $(28,29)$.

\section{Serum $E_{2}$ and bone growth in men}

The traditional view was that estrogens and androgens were the main sex steroids influencing bone maturation and maintenance in women and men respectively. This concept has, however, been challenged in the 1990's by the description of several 'experiments of nature'. In 1994, Smith et al. described a 28 -year-old man with a naturally occurring mutation in the $E R \alpha$ gene, making him resistant to estrogen (30). This patient had undergone normal early growth and developed normal male secondary sexual characteristics, but had unfused epiphyses and a markedly delayed bone age of 15 years. He was tall and had experienced no pubertal growth spurt, suggesting continued linear growth into adulthood. Moreover, despite normal serum $\mathrm{T}$ levels and elevated $\mathrm{E}_{2}$ levels, he had severe osteopenia associated with elevated markers of bone remodeling. Henceforth, two men with estrogen deficiency, due to mutations in the aromatase (CYP19) gene, were described $(31,32)$. These individuals had undetectable $\mathrm{E}_{2}$ levels and almost identical skeletal phenotypes as the estrogenresistant man, regardless of normal or elevated T levels. But, contrary to the estrogen-resistant male who had no response to estrogen therapy, these aromatasedeficient men responded to estrogen treatment with a significantly increased bone mass, suppression of bone resorption and growth plate closure $(32,33)$. 
Since then, several new cases of aromatase deficiency have been reported, all with similar baseline skeletal phenotypes as the landmark case report by Smith et al. (30). Estrogen replacement therapy, using different doses of $E_{2}$, in patients with aromatase deficiency has indicated that serum $\mathrm{E}_{2}$ levels above a threshold of $\sim 20 \mathrm{pg} / \mathrm{ml}$ are required to complete bone maturation and mineralization (32-35).

\section{Serum $E_{2}$ and bone maintenance in men}

In general, observational studies reported that serum $\mathrm{E}_{2}$ correlated better with $\mathrm{BMD}$ at various sites than $\mathrm{T}$ (36-45). Moreover, prospective studies have shown that serum $E_{2}$ was the best predictor of both the increase in bone mass in young men (46) and the decrease of bone density in elderly men (46-48). In addition, treatment of elderly men with an aromatase inhibitor resulted in significant increases in bone resorption, together with decreases in bone formation markers (49). This pivotal role of estrogen with respect to male skeletal metabolism has since been confirmed in several other studies. Importantly, Khosla et al. (46) suggested that, in elderly men, a threshold exists for bioavailable $E_{2}$ of $11 \mathrm{pg} / \mathrm{ml}$ $(40 \mathrm{pmol} / \mathrm{l})$, corresponding to a total $\mathrm{E}_{2}$ level of $31 \mathrm{pg} / \mathrm{ml}(114 \mathrm{pmol} / \mathrm{l})$, below which the rate of bone loss at the radius and the ulna was clearly associated with bioavailable $E_{2}$ levels. Above this level, no apparent association between the rate of bone loss and bioavailable $\mathrm{E}_{2}$ levels was found. Similar thresholds for serum $\mathrm{E}_{2}$ were reported in elderly men by Gennari et al. (48) for bone loss at the femoral neck and lumbar spine and by Szulc et al. (43) for changes in biochemical markers of bone turnover.

The majority of estrogens in elderly men do not originate from the testes but from peripheral conversion from androgens (50). Therefore, the extent of peripheral aromatase activity may also influence serum $E_{2}$ levels. Elderly men with a high number of repeats in the aromatase gene have been reported to have higher $\mathrm{E}_{2}$ levels and decreased rates of bone loss compared with men with a low number of repeats (51). In addition, this CYP19 repeat was significantly associated with BMD change in elderly community-dwelling men (47). These findings suggest that a genetic variation in the aromatase gene may predispose men to increased age-related bone loss, by modulating bone metabolism either directly or indirectly via altered serum $\mathrm{E}_{2}$ levels. This notion is supported by our earlier report that CYP19 polymorphisms were associated with BMD and cortical bone size in young adult Swedish men (52). Recently, our extensive evaluation of 604 single nucleotide polymorphisms (SNPs) in 50 sex steroidrelated candidate genes identified an SNP (rs 2470152) in the I.4 promoter region of the aromatase gene to be clearly associated with serum $\mathrm{E}_{2}$ levels in both young adults and elderly men $\left(P=10^{-14}\right)$ (53).
Importantly, subjects with the GG genotype of this CYP19 polymorphism did not only have markedly elevated $\mathrm{E}_{2}$ levels but also higher lumbar spine BMD and fewer prevalent fractures than subjects with the GA or AA genotypes. Interestingly, the $\mathrm{G}$ to A transition of rs2470152 is predicted to alter a potential binding site for the transcription factor cyclic AMP response element binding protein, which is thought to be important in regulating aromatase expression (54). Further studies are required to test the functional significance of this CYP19 promoter polymorphism on the expression of the CYP19 gene in bone and other relevant tissues, and to evaluate the impact of this polymorphism on sex steroid-related disorders (53). In addition, a recent paper from the European Male Aging Study reported that the CAG repeat length in the AR correlated to calcaneus ultrasound parameters and this was associated with increased estrogen rather than decreased androgen action (55).

\section{Serum $E_{2}$ and fractures in men}

Even though the above-mentioned studies provide strong evidence for an important role of estrogens for bone metabolism in men, little is known about the relative role of androgens and estrogens on fracture risk in men. In cross-sectional studies, inverse associations between both serum $\mathrm{E}_{2}(44,56)$ and $\mathrm{T}(44)$ and prevalent fractures have been shown. Still, the roles of serum $\mathrm{E}_{2}$ and $\mathrm{T}$ as predictors of fracture risk in men analyzed in large prospective studies remain contradictory (57-60). Previous conflicting results might be due to the fact that these earlier prospective studies have been underpowered, including few incident fractures, and most of them (57-59) have analyzed the baseline sex steroid levels using immunoassay-based techniques, which have been shown to have a questionable

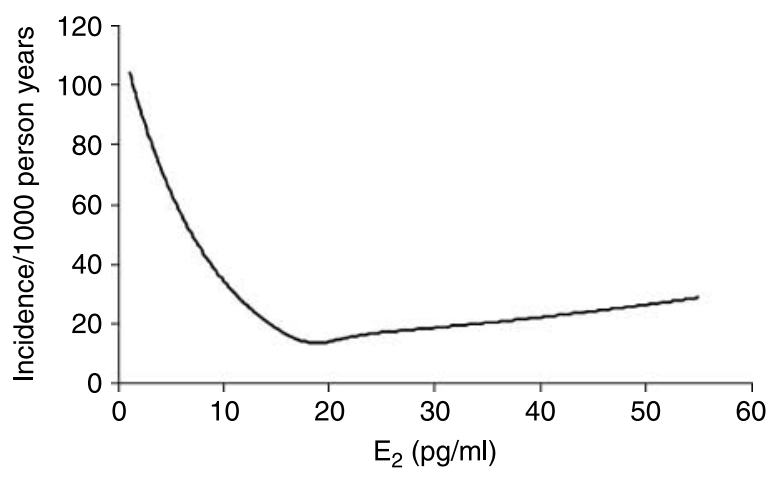

Figure $5 \mathrm{~A}$ threshold for the inverse relation between serum $\mathrm{E}_{2}$ and fracture risk. Yearly incidence of fractures in relation to total $E_{2}$. Poisson regression models were used to determine the relation between serum hormone levels and fracture risk (based on all validated fractures) in elderly subjects from the MrOS Sweden cohort. (Adapted from Mellström et al. (61) with permission from the American Society for Bone and Mineral Research). 
specificity, especially at lower concentrations. Most recently, we analyzed the predictive role of serum $E_{2}$ and $\mathrm{T}$ levels for incident fracture risk in the $\mathrm{MrOS}$ Sweden study, the largest population-based cohort so far with sex steroid levels measured at baseline with the mass spectrometry technique (61). We found that both serum $\mathrm{E}_{2}$ levels and $\mathrm{T}$ levels were inversely associated with fracture risk when analyzed separately. However, in multivariate analyses, serum free $\mathrm{E}_{2}$ was independently of free $\mathrm{T}$, a predictor of all fractures in these elderly men. Moreover, when analyzing the effect of having low $\mathrm{E}_{2}$ and/or low $\mathrm{T}$ levels, subjects with low serum $E_{2}$ levels had an increased risk of fractures, independent of T status. By contrast, subjects with low T levels but normal $\mathrm{E}_{2}$ levels were not at higher risk for fracture. In addition, the inverse relationship between serum $\mathrm{E}_{2}$ levels and fracture risk was nonlinear, with a strong relationship at total $\mathrm{E}_{2}$ levels below $16 \mathrm{pg} / \mathrm{ml}$ ( $59 \mathrm{pmol} / \mathrm{l}$; Fig. 5). This observation further confirms the concept of a threshold $E_{2}$ level for skeletal health in men (62). The threshold $\mathrm{E}_{2}$ level for fracture risk described in the MrOS Sweden Study (61) is slightly lower than those previously described for bone maturation, BMD and markers of bone resorption $(35,43$, $46,48)$. This difference could be due to the fact that in the latter studies, serum $\mathrm{E}_{2}$ was analyzed using immunoassay-based techniques, while it was analyzed by mass spectrometry in the Swedish cohort.

\section{Conclusions}

Experimental animal studies have demonstrated that both activation of $\mathrm{ER} \alpha$ and AR result in a stimulatory effect on bone mass in males. Recent human studies have gathered substantial evidence for the existence of a threshold $\mathrm{E}_{2}$ level in men for bone maturation, bone loss as well as fracture risk. Even though these findings do not exclude an important role for $\mathrm{T}$ in male skeletal homeostasis, they do provide proof of an important role for estrogen in bone health in men.

\section{Declaration of interest}

The authors have no conflicts of interest.

\section{Funding}

Our research cited in this review is funded by the Swedish Research Council, the Swedish Foundation for Strategic Research, The ALF/LUA research grant in Gothenburg, the Lundberg Foundation, the Torsten and Ragnar Söderberg's Foundation, Petrus and Augusta Hedlunds Foundation, and the Novo Nordisk Foundation.

\section{References}

1 Riggs BL, Khosla S \& Melton LJ. Sex steroids and the construction and conservation of the adult skeleton. Endocrine Reviews 200223 279-302.
2 Vanderschueren D, Vandenput L, Boonen S, Lindberg MK, Bouillon R \& Ohlsson C. Androgens and bone. Endocrine Reviews 200425 389-425.

3 Nilsson LO, Boman A, Savendahl L, Grigelioniene G, Ohlsson C, Ritzen EM \& Wroblewski J. Demonstration of estrogen receptorbeta immunoreactivity in human growth plate cartilage. Journal of Clinical Endocrinology and Metabolism 199984 370-373.

4 Vidal O, Kindblom LG \& Ohlsson C. Expression and localization of estrogen receptor-beta in murine and human bone. Journal of Bone and Mineral Research 199914 923-929.

5 Revankar CM, Cimino DF, Sklar LA, Arterburn JB \& Prossnitz ER. A transmembrane intracellular estrogen receptor mediates rapid cell signaling. Science 2005307 1625-1630.

6 Venken K, De Gendt K, Boonen S, Ophoff J, Bouillon R, Swinnen JV, Verhoeven G \& Vanderschueren D. Relative impact of androgen and estrogen receptor activation in the effects of androgens on trabecular and cortical bone in growing male mice: a study in the androgen receptor knockout mouse model. Journal of Bone and Mineral Research 200621 576-585.

7 Vidal O, Lindberg MK, Hollberg K, Baylink DJ, Andersson G, Lubahn DB, Mohan S, Gustafsson JA \& Ohlsson C. Estrogen receptor specificity in the regulation of skeletal growth and maturation in male mice. PNAS 200097 5474-5479.

8 Sjogren K, Sheng M, Moverare S, Liu JL, Wallenius K, Törnell J, Isaksson O, Jansson JO, Mohan S \& Ohlsson C. Effects of liverderived insulin-like growth factor I on bone metabolism in mice. Journal of Bone and Mineral Research 200217 1977-1987.

9 Sjogren K, Liu JL, Blad K, Skrtic S, Vidal O, Wallenius V, LeRoith D, Tornell J, Isaksson OG, Jansson JO \& Ohlsson C. Liver-derived insulin-like growth factor I (IGF-I) is the principal source of IGF-I in blood but is not required for postnatal body growth in mice. PNAS 199996 7088-7092.

10 Yakar S, Liu JL, Stannard B, Butler A, Accili D, Sauer B \& LeRoith D. Normal growth and development in the absence of hepatic insulin-like growth factor I. PNAS 199996 7324-7329.

11 Yakar S, Rosen CJ, Beamer WG, Ackert-Bicknell CL, Wu Y, Liu JL, Ooi GT, Setser J, Frystyk J, Boisclair YR \& LeRoith D. Circulating levels of IGF-1 directly regulate bone growth and density. Journal of Clinical Investigation $2002 \mathbf{1 1 0} 771-781$.

12 Lindberg MK, Moverare S, Skrtic S, Alatalo S, Halleen J, Mohan S, Gustafsson JA \& Ohlsson C. Two different pathways for the maintenance of trabecular bone in adult male mice. Journal of Bone and Mineral Research 200217 555-562.

13 Moverare S, Venken K, Eriksson AL, Andersson N, Skrtic S, Wergedal J, Mohan S, Salmon P, Bouillon R, Gustafsson JA, Vanderschueren D \& Ohlsson C. Differential effects on bone of estrogen receptor $\alpha$ and androgen receptor activation in orchidectomized adult male mice. PNAS $2003 \mathbf{1 0 0} 13573-13578$.

14 Vandenput L, Ederveen AG, Erben RG, Stahr K, Swinnen JV, Van Herck E, Verstuyf A, Boonen S, Bouillon R \& Vanderschueren D. Testosterone prevents orchidectomy-induced bone loss in estrogen receptor-alpha knockout mice. Biochemical and Biophysical Research Communications 2001285 70-76.

15 Lindberg MK, Alatalo SL, Halleen JM, Mohan S, Gustafsson JA \& Ohlsson C. Estrogen receptor specificity in the regulation of the skeleton in female mice. Journal of Endocrinology $2001 \mathbf{1 7 1}$ 229-236.

16 Lindberg MK, Weihua Z, Andersson N, Moverare S, Gao H, Vidal O, Erlandsson M, Windahl S, Andersson G, Lubahn DB, Carlsten H, Dahlman-Wright K, Gustafsson JA \& Ohlsson C. Estrogen receptor specificity for the effects of estrogen in ovariectomized mice. Journal of Endocrinology 2002174 167-178.

17 Sims NA, Clement-Lacroix P, Minet D, Fraslon-Vanhulle C, Gaillard-Kelly M, Resche-Rigon M \& Baron R. A functional androgen receptor is not sufficient to allow estradiol to protect bone after gonadectomy in estradiol receptor-deficient mice. Journal of Clinical Investigation 2003111 1319-1327.

18 Sims NA, Dupont S, Krust A, Clement-Lacroix P, Minet D, Resche-Rigon M, Gaillard-Kelly M \& Baron R. Deletion of estrogen 
receptors reveals a regulatory role for estrogen receptors-beta in bone remodeling in females but not in males. Bone 200230 $18-25$.

19 Windahl SH, Vidal O, Andersson G, Gustafsson JA \& Ohlsson C. Increased cortical bone mineral content but unchanged trabecular bone mineral density in female $\operatorname{ERbeta}(-/-)$ mice. Journal of Clinical Investigation 1999104 895-901.

20 Windahl SH, Hollberg K, Vidal O, Gustafsson JA, Ohlsson C \& Andersson G. Female estrogen receptor beta-/- mice are partially protected against age-related trabecular bone loss. Journal of Bone and Mineral Research 200116 1388-1398.

21 Lindberg MK, Moverare S, Skrtic S, Gao H, Dahlman-Wright K, Gustafsson JA \& Ohlsson C. Estrogen receptor (ER)-beta reduces ERalpha-regulated gene transcription, supporting a 'Ying Yang' relationship between ERalpha and ERbeta in mice. Molecular Endocrinology 200317 203-208.

22 Thomas P, Pang Y, Filardo EJ \& Dong J. Identity of an estrogen membrane receptor coupled to a $\mathrm{G}$ protein in human breast cancer cells. Endocrinology 2005146 624-632.

23 Filardo EJ, Quinn JA, Frackelton AR Jr \& Bland KI. Estrogen action via the $G$ protein-coupled receptor, GPR30: stimulation of adenylyl cyclase and cAMP-mediated attenuation of the epidermal growth factor receptor-to-MAPK signaling axis. Molecular Endocrinology 200216 70-84.

24 Maggiolini M, Vivacqua A, Fasanella G, Recchia AG, Sisci D, Pezzi V, Montanaro D, Musti AM, Picard D \& Ando S. The G protein-coupled receptor GPR30 mediates c-fos up-regulation by 17beta-estradiol and phytoestrogens in breast cancer cells. Journal of Biological Chemistry 2004279 27008-27016.

25 Vivacqua A, Bonofiglio D, Recchia AG, Musti AM, Picard D, Ando S \& Maggiolini M. The G protein-coupled receptor GPR30 mediates the proliferative effects induced by 17 beta-estradiol and hydroxytamoxifen in endometrial cancer cells. Molecular Endocrinology 200620 631-646.

26 Prossnitz ER, Arterburn JB, Smith HO, Oprea TI, Sklar LA \& Hathaway HJ. Estrogen signaling through the transmembrane G protein-coupled receptor GPR30. Annual Review of Physiology 200870 165-190.

27 Prossnitz ER, Sklar LA, Oprea TI \& Arterburn JB. GPR30: a novel therapeutic target in estrogen-related disease. Trends in Pharmacological Sciences 200829 116-123.

28 Windahl SH, Andersson N, Chagin AS, Martensson UE, Carlsten H, Olde B, Swanson C, Moverare-Skrtic S, Savendahl L, Lagerquist MK, Leeb-Lundberg LM \& Ohlsson C. The role of the G protein-coupled receptor GPR30 in the effects of estrogen in ovariectomized mice. American Journal of Physiology. Endocrinology and Metabolism 2009296 E490-E496.

29 Martensson UE, Salehi SA, Windahl S, Gomez MF, Sward K, Daszkiewicz-Nilsson J, Wendt A, Andersson N, Hellstrand P, Grande PO, Owman C, Rosen CJ, Adamo ML, Lundquist I, Rorsman P, Nilsson BO, Ohlsson C, Olde B \& Leeb-Lundberg LM. Deletion of the $\mathrm{G}$ protein-coupled receptor 30 impairs glucose tolerance, reduces bone growth, increases blood pressure, and eliminates estradiol-stimulated insulin release in female mice. Endocrinology $2009150687-698$.

30 Smith EP, Boyd J, Frank GR, Takahashi H, Cohen RM, Specker B, Williams TC, Lubahn DB \& Korach KS. Estrogen resistance caused by a mutation in the estrogen-receptor gene in a man. New England Journal of Medicine 1994331 1056-1061.

31 Morishima A, Grumbach MM, Simpson ER, Fisher C \& Oin K. Aromatase deficiency in male and female siblings caused by a novel mutation and the physiological role of estrogens. Journal of Clinical Endocrinology and Metabolism $1995 \mathbf{8 0} 3689-3698$.

32 Carani C, Qin K, Simoni M, Faustini-Fustini M, Serpente S, Boyd J, Korach KS \& Simpson ER. Effect of testosterone and estradiol in a man with aromatase deficiency. New England Journal of Medicine 1997337 91-95.

33 Bilezikian JP, Morishima A, Bell J \& Grumbach MM. Increased bone mass as a result of estrogen therapy in a man with aromatase deficiency. New England Journal of Medicine 1998339 599-603.
34 Lanfranco F, Zirilli L, Baldi M, Pignatti E, Corneli G, Ghigo E, Aimaretti G, Carani C \& Rochira V. A novel mutation in the human aromatase gene: insights on the relationship among serum estradiol, longitudinal growth and bone mineral density in an adult man under estrogen replacement treatment. Bone $2008 \mathbf{4 3}$ 628-635.

35 Rochira V, Faustini-Fustini M, Balestrieri A \& Carani C. Estrogen replacement therapy in a man with congenital aromatase deficiency: effects of different doses of transdermal estradiol on bone mineral density and hormonal parameters. Journal of Clinical Endocrinology and Metabolism 200085 1841-1845.

36 Greendale GA, Edelstein S \& Barrett-Connor E. Endogenous sex steroids and bone mineral density in older women and men: the Rancho Bernardo study. Journal of Bone and Mineral Research 1997 12 1833-1843.

37 Slemenda CW, Longcope C, Zhou L, Hui SL, Peacock M \& Johnston CC. Sex steroids and bone mass in older men. Positive associations with serum estrogens and negative associations with androgens. Journal of Clinical Investigation 1997100 1755-1759.

38 Khosla S, Melton LJ III, Atkinson EJ, O'Fallon WM, Klee GG \& Riggs BL. Relationship of serum sex steroid levels and bone turnover markers with bone mineral density in men and women: a key role for bioavailable estrogen. Journal of Clinical Endocrinology and Metabolism $1998 \mathbf{8 3} 2266-2274$.

39 Ongphiphadhanakul B, Rajatanavin R, Chanprasertyothin S, Piaseu N \& Chailurkit L. Serum oestradiol and oestrogen-receptor gene polymorphism are associated with bone mineral density independently of serum testosterone in normal males. Clinical Endocrinology $1998 \mathbf{4 9} 803-809$.

40 Center JR, Nguyen TV, Sambrook PN \& Eisman JA. Hormonal and biochemical parameters in the determination of osteoporosis in elderly men. Journal of Clinical Endocrinology and Metabolism 1999 $843626-3635$.

41 Amin S, Zhang Y, Sawin CT, Evans SR, Hannan MT, Kiel DP, Wilson PW \& Felson DT. Association of hypogonadism and estradiol levels with bone mineral density in elderly men from the Framingham study. Annals of Internal Medicine 2000133 951-963.

42 van den Beld AW, de Jong FH, Grobbee DE, Pols HA \& Lamberts SW. Measures of bioavailable serum testosterone and estradiol and their relationships with muscle strength, bone density, and body composition in elderly men. Journal of Clinical Endocrinology and Metabolism 200085 3276-3282.

43 Szulc P, Munoz F, Claustrat B, Garnero P, Marchand F, Duboeuf F \& Delmas PD. Bioavailable estradiol may be an important determinant of osteoporosis in men: the MINOS study. Journal of Clinical Endocrinology and Metabolism 200186 192-199.

44 Mellstrom D, Johnell O, Ljunggren O, Eriksson AL, Lorentzon M, Mallmin H, Holmberg A, Redlund-Johnell I, Orwoll E \& Ohlsson C. Free testosterone is an independent predictor of BMD and prevalent fractures in elderly men: MrOS Sweden. Journal of Bone and Mineral Research 200621 529-535.

45 Araujo AB, Travison TG, Leder BZ \& McKinlay JB. Correlations between serum testosterone, estradiol, and sex hormone-binding globulin and bone mineral density in a diverse sample of men. Journal of Clinical Endocrinology and Metabolism 200893 2135-2141.

46 Khosla S, Melton LJ III, Atkinson EJ \& O’Fallon WM. Relationship of serum sex steroid levels to longitudinal changes in bone density in young versus elderly men. Journal of Clinical Endocrinology and Metabolism 200186 3555-3561.

47 Van Pottelbergh I, Goemaere S \& Kaufman JM. Bioavailable estradiol and an aromatase gene polymorphism are determinants of bone mineral density changes in men over 70 years of age. Journal of Clinical Endocrinology and Metabolism $2003 \mathbf{8 8}$ 3075-3081.

48 Gennari L, Merlotti D, Martini G, Gonnelli S, Franci B, Campagna S, Lucani B, Dal Canto N, Valenti R, Gennari C \& Nuti R. Longitudinal association between sex hormone levels, bone loss, and bone turnover in elderly men. Journal of Clinical Endocrinology and Metabolism 200388 5327-5333. 
49 Taxel P, Kennedy DG, Fall PM, Willard AK, Clive JM \& Raisz LG. The effect of aromatase inhibition on sex steroids, gonadotropins, and markers of bone turnover in older men. Journal of Clinical Endocrinology and Metabolism 200186 2869-2874.

50 Kaufman JM \& Vermeulen A. The decline of androgen levels in elderly men and its clinical and therapeutic implications. Endocrine Reviews 200526 833-876.

51 Gennari L, Masi L, Merlotti D, Picariello L, Falchetti A, Tanini A, Mavilia C, Del Monte F, Gonnelli S, Lucani B, Gennari C \& Brandi ML. A polymorphic CYP19 TTTA repeat influences aromatase activity and estrogen levels in elderly men: effects on bone metabolism. Journal of Clinical Endocrinology and Metabolism $2004892803-2810$.

52 Lorentzon M, Swanson C, Eriksson AL, Mellstrom D \& Ohlsson C. Polymorphisms in the aromatase gene predict areal BMD as a result of affected cortical bone size: the GOOD study. Journal of Bone and Mineral Research 200621 332-339.

53 Eriksson AL, Lorentzon M, Vandenput L, Labrie F, Lindersson M, Syvanen AC, Orwoll ES, Cummings SR, Zmuda JM, Ljunggren O, Karlsson MK, Mellstrom D \& Ohlsson C. Genetic variations in sex steroid-related genes as predictors of serum estrogen levels in men. Journal of Clinical Endocrinology and Metabolism 2009 94 1033-1041.

54 Sofi M, Young MJ, Papamakarios T, Simpson ER \& Clyne CD. Role of CRE-binding protein (CREB) in aromatase expression in breast adipose. Breast Cancer Research and Treatment 2003 79 399-407.

55 Huhtaniemi IT, Pye SR, Limer KL, Thomson W, O'Neill TW, Platt H, Payne D, John SL, Jiang M, Boonen S, Borghs H, Vanderschueren D, Adams JE, Ward KA, Bartfai G, Casanueva F, Finn JD, Forti G, Giwercman A, Han TS, Kula K, Lean ME, Pendleton N, Punab M, Silman AJ \& Wu FC. Increased estrogen rather than decreased androgen action is associated with longer androgen receptor CAG repeats. Journal of Clinical Endocrinology and Metabolism $200994277-284$.

56 Barrett-Connor E, Mueller JE, von Muhlen DG, Laughlin GA Schneider DL \& Sartoris DJ. Low levels of estradiol are associated with vertebral fractures in older men, but not women: the Rancho Bernardo Study. Journal of Clinical Endocrinology and Metabolism 200085 219-223.

57 Amin S, Zhang Y, Felson DT, Sawin CT, Hannan MT, Wilson PW \& Kiel DP. Estradiol, testosterone, and the risk for hip fractures in elderly men from the Framingham Study. American Journal of Medicine 2006119 426-433.

58 Bjornerem A, Ahmed LA, Joakimsen RM, Berntsen GK, Fonnebo V, Jorgensen L, Oian P, Seeman E \& Straume B. A prospective study of sex steroids, sex hormone-binding globulin, and non-vertebral fractures in women and men: the Tromso Study. European Journal of Endocrinology 2007157 119-125.

59 Goderie-Plomp HW, van der Klift M, de Ronde W, Hofman A, de Jong FH \& Pols HA. Endogenous sex hormones, sex hormonebinding globulin, and the risk of incident vertebral fractures in elderly men and women: the Rotterdam Study. Journal of Clinical Endocrinology and Metabolism $2004893261-3269$.

60 Meier C, Nguyen TV, Handelsman DJ, Schindler C, Kushnir MM, Rockwood AL, Meikle AW, Center JR, Eisman JA \& Seibel MJ. Endogenous sex hormones and incident fracture risk in older men: the Dubbo Osteoporosis Epidemiology Study. Archives of Internal Medicine $2008 \mathbf{1 6 8} 47-54$.

61 Mellstrom D, Vandenput L, Mallmin H, Holmberg AH, Lorentzon M, Oden A, Johansson H, Orwoll ES, Labrie F, Karlsson MK, Ljunggren $\mathrm{O} \&$ Ohlsson $\mathrm{C}$. Older men with low serum estradiol and high serum SHBG have an increased risk of fractures. Journal of Bone and Mineral Research 200823 1552-1560.

62 Khosla S, Melton LJ III \& Riggs BL. Estrogen and the male skeleton. Journal of Clinical Endocrinology and Metabolism $2002 \mathbf{8 7}$ 1443-1450.

Received 18 March 2009

Accepted 19 March 2009 